\title{
LITERASI MEDIA SEBAGAI STRATEGI KOMUNIKASI TIM SUKSES RELAWAN PEMENANGAN PEMILIHAN PRESIDEN Jokowi JK DI BANDUNG
}

\author{
Annisa Senova \\ Universitas Islam Bandung
}

\begin{abstract}
ABSTRAK
Memahami kegiatan literasi media yang terjadi dalam kehidupan berorganisasi akan memberikan gambaran yang jelas tentang kemampuan mengidentifikasi, menentukan, mengorganisir, dan menggunakan media, serta menjadikan informasi sebagai bahan pertimbangan pembuatan keputusan tim sukses relawan pemenangan Presiden Joko Widodo dan Jusuf Kalla di Bandung. Oleh karena itu, penelitian ini dilakukan untuk menemukan kegiatan literasi media sebagai strategi komunikasi tim sukses relawan pemenangan pemilihan presiden Joko Widodo dan Jusuf Kalla. Metode yang digunakan dalam penelitian ini adalah metode kualitatif dengan pendekatan studi kasus. Penelitian ini menggunakan teknik pengumpulan data berupa wawancara mendalam, observasi, dan studi dokumentasi. Teknik pemeriksaan keabsahan data yang digunakan dalam penelitian ini adalah dengan triangulasi data sumber. Media sosial menjadi media utama dalam proses penyampaian pesan kepada khalayak di kota Bandung. Terdapat beberapa jenis media sosial yang akan digunakan secara rutin dalam proses tersebut, yaitu Twitter, Facebook, Instagram, dan Youtube. Namun, timses relawan media sosial hanya fokus kepada dua jenis media sosial yang dianggap dapat mempengaruhi pandangan publik. Twiter dan Instagram dianggap mampu menjadi jejaring sosial yang efektif dalam proses penyampaian pesan politik pemilu 2014. Penyampaian informasi oleh timses relawan media sosial kepada masyarakat melalui Twitter dan Instagram dianggap sangat efektif dan tepat. Konten-konten yang disediakan oleh akun Twitter sangat mudah untuk diakses oleh semua kalangan. Penelitian tantang proses literasi media tim sukses relawan pemenangan presiden Jokowi-Jk ini dapat menambah masukan bagi ilmu komunikasi, terutama dalam bidang literasi media, bahwa saat ini keberadaan media dapat menjadi sebuah strategi komunikasi yang cukup efektif.
\end{abstract}

Kata-kata kunci: Literasi media, komunikasi politik, strategi komunikasi, manajemen reputasi, tim sukses relawan

\section{MEDIA LITERACY AS COMMUNICATION STRATEGY BY Jokowi JK PRESIDENTIAL WINNING ELECTION SUCCESS VOLUNTEER TEAM IN BANDUNG}

\section{ABSTRACT}

Knowing the activity of media literacy that happened in organization's life, will give a real description about identification skill, determineskill, organization skill, and use themedia, alsomakethe information as consideration to make decision for volunteers team's Joko Widodo and Jusuf Kalla in Bandung. This research happen to find the activity of media literacy as communication strategy by Joko Widodo and Jusuf Kalla's volunteers team. This reaserch used kualitatif as a method with case study approach. This reaserch used data collection technique be in form of deep interview, observation, and documentation study. The validity examination with triangulation data's resource. Information spreaded by Joko Widodo and Jusuf Kalla's volunteers team to the community through social media Twitter and Instagram considered very effective and appropriate. Content that is provided by the Twitter and Instagram account is very easy to access by all people. The study of this media literacy process of Jokowi-JK president volunteer campaign team can add input to challenge communication science, especially in the field of media literacy, that now the existence of the media can be an effective communication strategy.

Keywords: Media literacy, political communication, communication strategy, reputation management, volunteers team

\section{PENDAHULUAN}

Korespondensi: Annisa Senova, S.Sos., M. I. Kom. Universitas Islam Bandung. Jl. Hariangbanga No.2, Tamansari, Bandung Wetan, Kota Bandung, Jawa Barat 40132.Email: senova.annisa@gmail.com 
Tim sukses menjadi salah satu faktor utama keberhasilan sebuah proses pemilihan umum di suatu Negara, hal ini juga merupakan tugas berat yang dihadapi oleh tim sukses relawan pemenangan presiden Jokowi-Jk dalam pemilu tahun 2014. Tim sukses harus memiliki tujuan yang fokus dan spesifik serta konsisten agar dapat menjalankan tugas-tugasnya secara efisien. Dalam menunjang hal tersebut mereka dituntut memiliki kecakapan dalam mencari data yang akurat, data-data tersebut akan dikelola menjadi sebuah informasi yang jelas dan bermanfaat dalam proses pemenangan pemilihan presiden. Dalam proses pencarian informasi yang dibutuhkan, tim sukses harus benar-benar mendapatkan informasi yang bisa dipertanggung jawabkan kepada publik nantinya, tentu saja informasi tersebut adalah informasi berdasarkan sumber-sumber yang valid.

Masyarakat Indonesia adalah masyarakat yang beraneka ragam, hal ini dapat dilihat dari berbagai sudut pandang seperti latar belakang pendidikan, adat budaya, agama, latar belakang sosial, dan politik. keadaan seperti ini membuat Negara Indonesia memiliki masyarakat yang mempunyai perbedaan-perbedaan perspektif dari segi apapun tidak terkecuali sudut pandang politiknya. Dikenal sebagai masyarat yang demokratis, masyarakat indonesia memiliki hak untuk memilih pemimpin yang sesuai dengan kriteria masing-masing. Teori demokrasi klasik mendefinisikan demokrasi dengan istilah-istilah "kehendak rakyat". (The will of people); sumber dan tujuan "kebaikan bersama" (the commond good), diruntuhkan oleh Scumpeter melalu apa yang ia namakan "teori lain mengenai demokrasi," yaitu "metode demokrasi" adalah prosedur kelembagaan untuk mencapai keputusan politik yang didalamnya individu memperoleh kekuasaan untuk membuat keputusan melalui perjuangan kompetitif dalam rangka memperoleh suara (Efriza, 2008: 109). Dengan demikian demokrasi juga bisa diartikan sebagai suatu bentuk sistem pemerintahan yang tertata dan terorganisir berdasarkan prinsip kedaulatan rakyat, kepentingan rakyat, berdasarkan keputusan bersama, kesamaan politik, dan aturan mayoritas.

Dari pengertian demokrasi yang telah dikemukakan oleh Efriza, maka dalam sudut pandang tertentu, demokrasi memiliki kelebihan dan kekurangan dalam menjalankan suatu sistem pemerintahan, ada yang berhasil ada juga yang malah membuat sistem pemerintahan semakin tidak berjalan baik dikarenakan satu dan lain hal. Demokrasi merupakan cara yang dianggap ideal dalam menentukan sistem pemerintahan suatu negara karena hasilnya murni berdasarkan pilihan rakyat, yang artinya adalah ditentukan atas dasar pilihan dari mayoritas, tetapi disisi lain demokrasi juga memiliki kekurangan karena hal ini bukan merupakan suatu sistem politik yang murni dan secara benar diterapkan oleh rakyat.

Terlepas dari asumsi-asumsi tentang demokrasiyang sudah dijelaskandiatas, bangsa Indonesia juga menganut sistem pemerintah yang demokrasi, walaupun tidak sedikit pihak yang mengatakan bahwa negara ini belum sepenuhnya berdemokrasi, setidaknya sudah ada unsur-unsur demokrasi yang dilaksanakan bangsa Indonesia yaitu dengan memilih presiden dan wakil rakyat secara langsung. Menurut UUD 1945 telah menetapkan bahwa Negara Kesatuan Republik Indonesia menganut paham atau ajaran demokrasi, dimana kedaulatan (kekuasaan tertinggi) berada ditangan Rakyat dan dilaksanakan sepenuhnya oleh Majelis Permusyawaratan Rakyat (MPR). Dari pernyataan diatas bisa disimpulkan bahwa negara Indonesia sebenarnya sudah cukup lama menganut sistem demokrasi, tetapi seiring berjalannya waktu dan pergantian kepemimpinan, sistem demokrasi pun berubah. Undang-undang Republik Indonesia nomor 15 tahun 2011 pasal 1 ayat 1 menjelaskan bahwa pemilu adalah sarana pelaksanaan kedaulatan rakyat yang diselenggarakan secara langsung, umum, bebas, rahasia, jujur, dan adil dalam Negara Kesatuan Republik Indonesia berdasarkan pancasila dan Undang-undang Dasar Negara Republik Indonesia Tahun 1945. (Budiarti dan Huda, 2013: 51)

Pada tahun 2014 ini seluruh rakyat indonesia secara bersamaan memilih wakil rakyat mulai dari DPD, DPRD, dan DPR RI serta memilih presiden secara langsung untuk masa kepemimpinan lima tahun kedepan. Sudah tiga periode rakyat indonesia memilih presidennya secara langsung, dimulai dari terpilihnya Presiden Susilo Bambang Yudhoyono hingga Joko Widodo sebagai presiden terpilih periode 
tahun 2014 sampai 2019. Pemilihan presiden adalah salah satu dari lima unsur dan syarat pokok terbentuknya suatu negara yaitu adanya pemerintah yang berfungsi mengurus dan memimpin negara. Pemerintahan dapat diartikan sebagai organisasi yang memiliki hak untuk melaksanakan kewenangan berdaulat atau tertinggi. Pemerintah dalam arti luas merupakan sesuatu yang lebih besar dari pada suatu kementrian yang diberi tanggungjawab memelihara perdamaian dan keamanan negara (Hasan, 2005: 2). Tugas pokok pemerintahan antara lain adalah menciptakan kondisi yang kondusif dan kestabil dalam suatu kehidupan bermasyarakat dibidang keamanan, ketertiban, keadilan, kesejahteraan sosial, ekonomi, pekerjaan umum, serta pemeliharaan sumber daya alam dan lingkungan hidup. Kembali kepada pemilihan presiden secara langsung, di tahun 2014 ini terjadi hal yang cukup fenomenal, Joko Widodo selaku Gubernur DKI Jakarta yang juga mantan walikota Surakarta, terpilih sebagai presiden ke tujuh negara Republik Indonesia yang terkenal dengan ciri khas "blusukan" nya, yang dianggap berhasil mendapatkan simpati masyarakat.

Pada awalnya Joko widodo berprofesi sebagai pengusaha asal kota surakarta, tahun 2005 beliau mengawali karir politiknya sebagai walikota surakarta selama dua periode, beliau berhasil membangun kota kelahirannya menjadi lebih baik. Banyak penghargaan dan pencapaian yang beliau peroleh dari dalam dan luar negeri, salah satunya terpilih dalam nominasi World Mayor 2012. tidak sampai disitu tahun 2012 beliau bersama Basuki Tjahaja Purnama atau lebih dikenal dengan panggilan "Ahok" mencalonkan diri sebagai pasangan gubernur dan wakil gubernur DKI Jakarta. Sifat yang merakyat dan mau mendengarkan keluhan masyarakat kecil dianggap sebagai sosok yang sangat ideal untuk memimpin ibu kota Negara Republik Indonesia. Akhirnya pada tanggal 15 Oktober 2012, Jokowi dan Ahok resmi dilantik sebagai gubernur dan wakil gubernur DKI Jakarta, dan diharapkan dapat memenuhi semua kriteria yang telah lama rindukan oleh seluruh lapisan masyarakat jakarta tentang sosok pemimpin yang mampu mendengar dan menyalurkan aspirasi rakyat.

Sangat erat kaitannya antara sosok Jokowi yang memiliki kepribadian yang dianggap cukup dicintai oleh masyarakat dengan bagaimana cara orang-orang yang ada dibelakangnya untuk membuat sosok Jokowi semakin menarik. Hal ini berkaitan dengan teori analisis framing dalam ilmu komunikasi. Analisis framing atau analisis aspek-aspek yang lain. Analisis bingkai merupakan dasar struktur kognitif yang memandu persepsi dan representasi realitas (Entman dalam Kamaruzzaman, 2015).

Beberapa ahli mengembangkan teori tentang analisis framing, antara lain adalah Zhongdang Pan dan Gerald M. kosicki serta William A. Gamson dan Andre Modigliani. Mereka mengembangkan teori ini dengan beberapa aspek kajian yang berbeda-beda. Zhongdang dan Gerald berfokus kepada membagi struktur analisis menjadi empat bagian, yaitu: (a) Sintaksis adalah cara wartawan menyususn berita, (b) Skrip adalah cara wartawan mengisahkan fakta, (c) Tematik adalah cara wartawan menulis fakta, dan (d) Retoris adalah cara wartawan menekankan fakta.

Selain dilihat dari kepribadian dan rekam jejak yang baik, Jokowi juga dikelilingi orang-orang yang memiliki kapasaitas dan dianggap mampu menjadi faktor pendukung keberhasilannya dalam pemilihan presiden. Orang-orang tersebut merupakan orang-orang yang dipilih dan dengan suka rela membantu proses pemenangan Jokowi, mereka tersebar diseluruh wilayah Indonesia, mereka memiliki tugas antara lain adalah membantu dalam proses kampanye, bersama-sama melakukan pengawasan terhadap proses pemilu agar berjalan lancar, membentuk citra pasangan presiden dan wakil presiden dihadapan masyarakat serta menjadi pihak-pihak yang secara langsung mengumpulkan informasi yang signifikan dan berdasarkan fakta dilapangan.

Tidak dapat dipungkiri, saat ini kita telah dihadapkan dengan zaman atau era globalilsasi informasi. Era globalisasi informasi merupakan fenomena yang terlihat sejak pertengahan tahun 1980-an dimana perkembangan di bidang teknologi informasi (komputer dan telekomunikasi) sedemikian pesatnya, sehingga kalau digambarkan secara grafis, kemajuan yang terjadi terlihat secara eksponensial (Hariningsih, 2005: 4). Yang artinya teknologi informasi berkembang sangat pesat dan berulang-ulang.

Pada hakikatnya Informasi diartikan sebagai suatu rekaman fenomena yang diamati, 
atau bisa juga berupa putusan-putusan yang dibuat seseorang (Estabook dalam Alhanin, 2009). Informasi bisa berupa kumpulan-kumpulan data yang dirangkum secara sistematis dan memiliki keabsahan atas isi yang terkandung didalamnya. Agar informasi yang dibutuhkan memiliki keakuratan, maka seseorang atau pihak yang mencari informasi tersebut harus mempunyai kemampuan yang mumpuni dalam menemukan informasi. Informasi yang tepat guna dapat bermanfaat dalam mendukung tugastugas atau untuk proses pengambilan keputusan dalam suatu lembaga.

Pada saat ini informasiberkembang dengan sangat pesat, informasi berkembang secara cepat dan berubah-ubah, alur informasi pun tidak bisa kita kendalikan, oleh sebab itu kita sebagai masyarakat yang berada dalam perkembangan tersebut dituntut untuk lebih jeli dan teliti dalam proses pencarian informasi tersebut. Pentingnya informasi menjadi sebuah trinitas yang seolah suci yaitu informasi, pendidikan dan hiburan, telah diakui sepenuhnya jauh sebelum populer istilah "masyarakat informasi" dan "teknologi informasi" dalam tahun 1970-an dan 1980an (Briggs dan Burke, 2006: 230). Kita harus dengan cermat mencari informasi dari sumbersumber yang bisa dipertanggungjawabkan kebenarannya. Sumber-sumber informasi akurat memudahkan kita untuk merangkum informasi secara cepat untuk berbagai kepentingan dan berguna juga untuk meningkatkan efisiensi dan efektivitas waktu. Penelusuran informasi bisa melalui banyak media, antara lain buku, kamus, ensiklopedia, abstrak, dan yang saat ini sering digunakan banyak masyarakat adalah media Internet.

Pada saat ini teknik pencarian informasi memiliki berbagai cara dengan sistem-sistem pendukung yang beragam, salah satunya kita mengenal istilah Literasi Informasi, secara definisi bahasa indonesia Information Literacy memiliki arti melek huruf. Menurut Shapiro dan Hughes (1996: 31) literasi informasi merupakan suatu konsep yang sering digunakan dalam proses pencarian informasi namun memiliki sifat ambigu atau tidak jelas. Banyak perbedaan pendapat dikalangan ahli tentang definisi literasi informasi, tetapi tidak memiliki perbedaan yang bergitu besar dan berarti dalam konsep dan prakteknya.

Paul Zurkowski adalah orang pertama yang memperkenalkan istilah Information
Literacy, menurutnya orang-orang yang literer adalah orang-orang yang terlatih dalam aplikasi sumberdaya dalam pekerjaannya (Behrens dalam Basuki, 2013). Seiring berjalannya waktu dan perkembangannya, pada tahun 2005 ditentukan kesepakatan tentang definisi Literasi informasi oleh IFLA, UNESCO dan National Forum for Information Literacy (NFIL) yaitu:

"Information literacy encompasses knowledge of one's information concerns and needs, and the ability to identify, locate, evaluate, organize, and effectively create, use and communicate information to address issues or problems at hand; it is a prerequisite for participating effectively in the Information Society and is part of the basic human right of life - long learning"

Yang artinya adalah informasi literacy meliputisalahsatuinformasiygberhubunganserta kebutuhan dan kemampuan untuk mengenali, mengalokasi, mengavaluasi, mengorganisir, menciptakan secara efektif, menggunakan dan mengkomunikasi kan informasi untuk menunjukkan suatu permasalahan dalam suatu wacana, dan merupakan suatu persyaratan untuk bergabung kedalam masyarakat informasi yang efektif serta menjadi bagian dasar dalam hak kehidupan manusia yaitu terus belajar.

Literasi informasi bisa diartikan pula sebagai bentuk kajian ilmu informasi dan perpustakaan yang memiliki fokus kepada kemampuan individu atau kelompok untuk mencari atau memperoleh, mengevaluasi dan menggunakan informasi tersebut untuk kebutuhan atau pemecahan masalah baik dalam skala kecil (pribadi) atau skala besar (masyarakat).

Banyak model-model literasi informasi yang memungkinkan untuk mencari tahu tentang komponen-komponen pendukung informasi serta untuk memusatkan pencarian informasi secara lebih efektif, terdapat 4 model yang terkenal dan sering digunakan dalam penelitian bidang ilmu informasi yaitu: The Big 6, Seven Pillars, dan Empowering 8 serta The Seven Faces of Information Literacy.

Berdasarkan sedikit penjelasan di atas tentang literasi informasi, maka terdapat kaitan yang cukup jelas dengan penelitian ini, dilihat 
dari fungsinya, dalam penelitian ini informasi yang akurat sangat bermanfaat bagi proses pemenangan calon Presiden Joko Widodo, bagaimana informasi tersebut menjadi suatu komponen yang sangat berpengaruh untuk menentukan strategi komunikasi selanjutnya, maka oleh sebab itu tim sukses dari calon presiden Joko Widodo dituntutuntuk menguasai literasi informasi karena hal tersebut merupakan kompetensi mutlak yang harus dimiliki untuk menunjang tugas mereka sebagai tim sukses. Dengan pencarian informasi yang akurat serta menggunakan media dan sumber yang tepat. tugas tim sukses yang menyediakan informasiinformasi terbaik guna mendukung program kerja agar berjalan sesuai dengan tujuan yang ingin dicapai. Literasi informasi juga akan membantu dalam kemampuan intelektual dan berfikir secara kritis serta berpendapat. Pencarian informasi melalui media massa adalah salah satu cara yang praktis dan cukup akurat untuk mendapatkan informasi yang dibutuhkan agar dapat dijadikan strategi pemenangan calon Presiden. Media massa tidak hanya sekedar memberikan informasi dan hiburan semata, tetapi juga mengajak khalayak untuk melakukan perubahan prilaku (Tamburaka, 2013: 1). Berdasarkan pernyataan tersebut, tentu saja sangat besar keterkaitannya antara keberadaan media massa dengan strategi pemenangan calon presiden karena media massa dapat mempengaruhi khalayak untuk lebih pintar dan selektif dalam proses pemilihan presiden.

Literasi media memiliki definisi yang kurang lebih sama dengan literasi informasi, terdiri dari dua suku kata yaitu media sebagai tempatpertukaranpesandaninformasisedangkan literasi berarti melek, secara umum lierasi media diartikan sebagai kemampuan khalayak yang melek terhadap media dan pesan media dalam konteks komunikasi massa (Tamburaka, 2013: 7). Association for Media Literacy menjelaskan hubungan antara media massa, pesan media, dan khalayak dibentuk dan dijelaskan dalam beberapa prinsip dasar nasional, yaitu: (1) Semua pesan media dibangun, (2) Setiap media memiliki karakteristik, kekuatan, dan keunikan membangun bahasa yang berbeda, (3) Pesan media diproduksi untuk suatu tujuan, (4) Semua pesan media berisi penanaman nilai tujuan yang ingin dicapai, (5) Manusia menggunakan kemampuan, keyakinan, dan pengalaman mereka untuk membangun arti pesan media, dan (6) Media dan pesan dapat mempengaruhi keyakinan, dan pengalaman mereka untuk membangun sendiri arti pesan media.

The Big6 adalah salah satu model literasi informasi yang sering digunakan dalam berbagai bidang kajian ilmu, menurut Michael B. Eisenberg dan Robert e. Berkowitz terdapat enam keterampilan dalam literasi informasi, yaitu perumusan masalah, strategi pencarian informasi, alokasi dan akses, pemanfaatan informasi, sintesis, dan evaluasi. Berdasarkan model the big6, dapat di integrasi kan kedalam literasi media khususnya media sosial yang berkaitan dalam penelitian ini.

Media sosial adalah salah satu media yang cukup berpengaruh untuk mempermudah orang-orang untuk berinteraksi satu sama lain, selain sifatnya yang praktis dan mudah diakses oleh penggunanya, media sosial juga sebagai tempat menyebarkan informasi kepada masyarakat secara luas. Informasi yang disebarkan melalui sosial media akan lebih mudah diterima oleh pengguna yang sudah memiliki kecakapan dalam mengakses informasi melalui berbagai jenis media sosial. Sama hal nya dengan informasi, menentukan media yang tepat akan berpengaruh besar terhadap kinerja suatu organisasi atau kelompok yang memiliki tujuan yang sama.

Penelitian ini memiliki fokus: Bagaimana Kegiatan literasi media sebagai strategi komunikasi tim sukses relawan pemenangan pemilihan presiden Joko Widodo-Jusuf Kalla di kota Bandung? permasalahan yang dipilh dan diteliti secara mendalam, difokuskan pada proses literasi media mereka untuk mendapatkan suara yang sudah ditargetkan sejak awal pembentukan tim sukses wilayah kota Bandung.

\section{METODE PENELITIAN}

Penelitian ini menggunakan metode kualitatif dengan pendekatan studi kasus, dalam konteks penelitian ini ingin memaparkan tentang proses-proses organisasi atau kelompok yang dilakukan oleh tim sukses pemenangan presiden Indonesia untuk wilayah Jawa Barat. Studi kasus memungkinkan peneliti untuk mempertahankan karakteristik holistik dan 
bermakna dari peristiwa kehidupan nyata seperti siklus kehidupan seseorang, proses-proses organisasi dan manajerial, perubahan lingkungan sosial, hubungan-hubungan internasiona, dan kematangan industri-industri (Yin, 2008: 4).

Teknik purposive sampling merupakan cara yang dipilih untuk digunakan dalam penelitian ini. Purposive sampling adalah sebuah teknik pengambilan sample dengan tujuan yang jelas dan secara sengaja sesuai dengan ketentuan sample yang dibutuhkan. Sampling bertujuan untuk memperoleh informasi dalam tahap pengumpulan data awal. Pada awalnya peneliti menelusuri informasi dari berbagai sumber yang ada berupa informan, komunitas-komunitas, tempat peristiwa, yang memiliki keterkaitan informasi dalam penelitian ini. Kriteria-kriteria berikut ini adalah cara menentukan informan, yaitu: (1) Tugas dan tanggung jawab dalam tim sukses relawan, alasan ini dipilih memenuhi kriteria karena biasanya semakin jelas fungsi, tugas, serta tanggung jawab anggota relawan maka akan semakin jelas pula informasi yang akan ditemukan, (2) Komunitas pengguna media, alasan ini dipilih memenuhi kriteria karena mereka adalah pengguna media yang aktif dan selalu mengakses serta memperbaharui informasi secara berkala, dan (3) Anggota komunitas serta pihak-pihak yang terkait langsung dalam proses pemenangan Presiden Joko Widodo-Jusuf Kalla, alasan ini dipilih memenuhi kriteria karena mereka adalah pihakpihak yang mengetahui dan terjun langsung dalam proses pemilihan umum.

Berikut ini adalah narasumber yang akan dijadikan sebagai subjek penelitian: (1) Fiki C. Satari, Anggota tim sukses relawan, tugas utamanya dalam proses pemenangan presiden Jokowi-Jk daerah pemilihan jawa barat sebagai ketua tim kampanye. Kampanye tersebut melalui temu langsung dengan masyarakat dan memberikan informasi kepada masyarakat melalui media sosial secara umum. Saat ini fiki satari juga menjabat sebagai ketua Bandung Creative City Forum (BCCF) periode 2013-2017. (2) Putri Khaira Ansuri, anggota tim sukses relawan, tugas utamanya dalam proses pemenangan presiden Jokowi-Jk daerah pemilihan jawa barat sebagai pengelola sosial media secara khusus, seperti twitter, youtube, facebook, dan segala bentuk media sosial lainnya., dan (3) Ebenz "burgerkill”, pengurus utama komunitas Rock N Roll Bandung, komunitas ini menjadi salah satu komunitas yang mendukung pemenangan presiden Jokowi-Jk. Mayoritas anggota dari komunitas ini menjadi voters untuk memilih presiden Jokowi.

Data primer dalam penelitian ini berupa informasiyangditerimalangsungdariwawancara mendalam berupa kata-kata yang diucapkan dan tindakan yang dilakukan oleh anggota tim sukses relawan pemenangan presiden Jokowi-Jk dalam kegiatan literasi media, serta anggota komunitas rock $\mathrm{n}$ roll sebagai salah satu komunitas voters yang menggunakan media sosial, dan memilih Jokowi-Jk. Data sekunder merupakan data atau informasi yang diperoleh tidak langsung untuk mendukung penelitian, data berupa observasi/ pengamatan, literatur-literatur, dokumentasi, foto-foto, serta studi pustaka yang berkaitan dengan peneltian untuk mendukung data primer.

\section{HASIL DAN PEMBAHASAN}

Berawal dari keinginan dan memiliki pandangan politik yang sejalan, beberapa orang dari kalangan dan profesi yang berbeda melakukan pertemuan sekaligus membentuk sebuah kelompok yang bergerak bersama-sama dalam rangka melaksanakan proses pemilihan umum. Perubahan gaya kepemimpinan seorang presiden yang sederhana, bersahaja, dan pro rakyat adalah faktor utama mengapa mereka memiliki pandangan politik yang sama. Berdasarkan pemikiran masing-masing kriteria kepemimpinan presiden tersebut cukup melekat pada sosok Joko Widodo, mantan walikota Surakarta ini, dianggap sangat dicintai oleh masyarakat karena memiliki kepribadian yang sederhana, mau turun ke jalan, mendengarkan keluhan-keluhan masyarakat, serta memiliki beberapa prestasi yang membanggakan baik dari dalam negeri maupun mancanegara.

Terlepas dari pro dan kontra yang menghampiri Joko Widodo, sekumpulan orangorang yang mengklaim dirinya sebagai komunitas relawan Jokowi ini tetap mendukung Jokowi untuk maju sebagai calon presiden Indonesia periode 2014-2019. Para pendukung calon presiden Jokowi tidak hanya dari kalangan pemerintahan di wilayah kota Bandung, tidak sedikit para pendukung berasal dari anggota komunitas- 
komunitas kreatif di sekitaran kota bandung. Awalnya anggota dari komunitas kreatif ini hanya melakukan pertemuan informal yang membahas tentang keberlansungan pemilu 2014, namun setelah terjadi beberapa kali pertemuan, mereka merasakan adanya persamaan visi dan misi. Visi dan misi tersebut dianggap memilki kesamaan dengan program kerja yang di ajukan oleh calon pasangan presiden Jokowi-Jk.

Terdapat beberapa jenis-jenis sosial media yang dipilih untuk dijadikan alat komunikasi oleh tim sukses relawan, antara lain: facebook, Twitter, youtube dan Instagram. Namun atas pertimbangan tim, kemungkinan tidak akan efektif jika menggunakan semua sosial media. Mereka akhirnya memilih dua jenis sosial media saja yang digunakan secara sistematis yang kontennya berisi tentang sudut pandang dan beberapa bukti di lapangan tentang kinerja seorang Joko Widodo. Media sosial Twitter dan Instagram akhirnya dipilih tim sukses relawan bagian sosial media yang menjadi penghubung antara tim sukses relawan dengan aspirasi warga Bandung.

Proses pemilihan media sosial yang akan dipergunakan dalam pemenangan presiden Jokowi di kota Bandung ini merupakan suatu proses yang cukup memakan waktu dan pikiran para anggota tim sukses relawan. Butuh lima kali pertemuan antara anggota timses untuk membahas masalah tersebut, banyaknya anggota yang berbeda pendapat menjadi salah satu kendala apakah media sosial secara terus menerus akan efektif dalam penggunaannya.

Timses relawan media sosial Jokowi$\mathrm{Jk}$ di kota Bandung telah mengidentifikasi kebutuhan apa saja yang sekiranya menjadi fokus di kalangan masyarakat sekitar kota Bandung. Sebelumnya telah dilakukan survei kepada orang-orang yang memiliki kriteriakriteria tertentu, survei tersebut berfokus kepada orang-orang yang dengan aktif menggunakan smartphone dalam melakukan aktifitas seharihari, contohnya pengusaha muda yang bergerak dibidang usaha kreatif di kota Bandung.

Proses penyampaian informasi melalui Twitter dan Instagram dari timses relawan kepada seluruh followers nya, tidak berhenti pada tahap ini saja. Pertukaran informasi yang juga terjadi melalui proses komunikasi kedua belah pihak yang terjadi di jejaring sosial tersebut akan dijadikan sumber informasi terbaru untuk timses relawan. Tanggapantanggapan yang diberikan langsung oleh publik akan dijadikan bahan pertimbangan oleh timses relawan untuk menyusun beritaberita yang akan di sebarkan berikutnya.

Tahap-tahap penyebaran informasi melalui jejaring sosial Instagram memiliki perbedaan yang cukup besar dengan jejaring sosial Twitter. Jika berita yang akan disampaikan melaui Twitter harus melalui beberapa tahap yang memakan waktu, penyebaran berita melaui Instagram lebih efisien dan singkat. Akun Instagram milik pribadi Joko Widodo hampir setiap hari mem posting kegiatan sehari-harinya, misalnya jika Jokowi sedang melakukan perjalanan dinas ke suatu daerah yang ada di pelosok Indonesia, beliau menyempatkan diri untuk melakukan tanya jawab dengan masyarakat sekitar tentang apa saja kendala yang terjadi di daerah tersebut, apa saja yang dibutuhkan dalam proses pembangunan daerah, dan seperti apa keadaan ekonomi mereka selama ini. Dikskusi yang terjadi antara Jokowi dengan warga masyarakat tersebut nantinya akan di dokumentasikan melalui kamera ponsel lalu langsung di posting dan diberikan sedikit penjelasan tentang apa yang sedang beliau lakukan dalam foto tersebut.

Pertukaran pesan pada akun Twitter@ pemilihcerdasid biasanya akan melewati beberapa proses untuk penggunaannya. Biasanya masyarakat kota Bandung sering mengajukan pertanyaan-pertanyaan sederhana tentang bagaimana proses pemilu yang ideal dan berdasarkan aturan yang berlaku, untuk pertanyaan-pertanyaan yang bersifat teoritis biasanya timses relawan akan menjawab secara singkat dan jelas tentang apa saja yang perlu diperhatikan dalam proses pemilu, misalnya apa saja yang termasuk dalam proses balck campaign, kemudian bagaimana tata cara yang sistematis dalam pemilihan presiden dan wakil rakyat. Jawaban-jawaban yang dijawab oleh timses relawan media sosial akan di posting secara langsung dan tampil di timeline akun Twitter@pemilihcerdasid.

Fokus penggunaan akun Twitter @ pemilihcerdasid oleh timses relawan media sosial Jokowi-Jk di kota Bandung lainnya adalah sebagai proses penyampaian informasi 


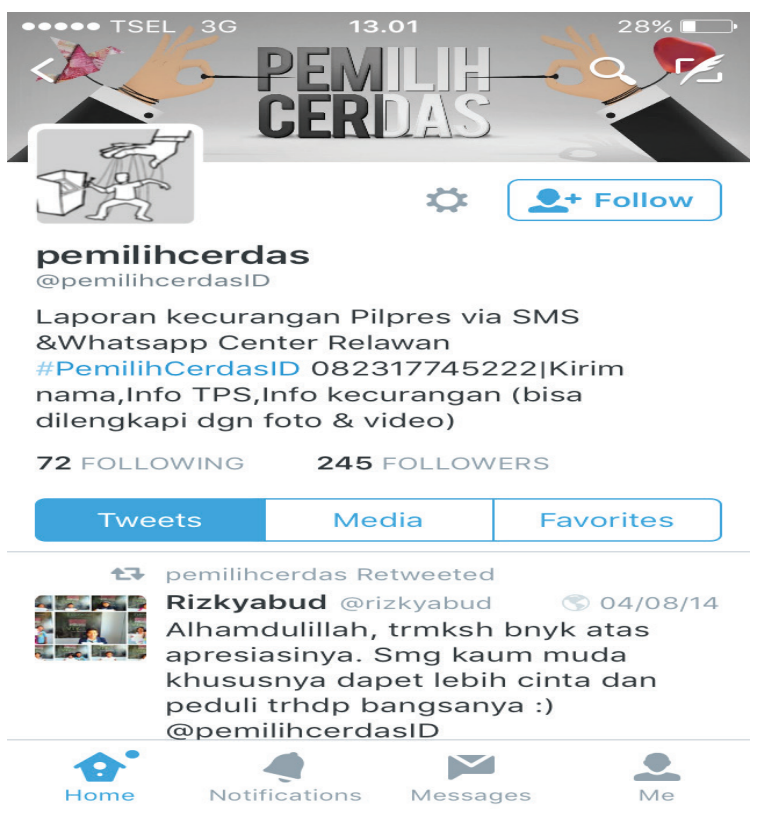

Gambar 1 Tampilan Twitter Pemilih Cerdas

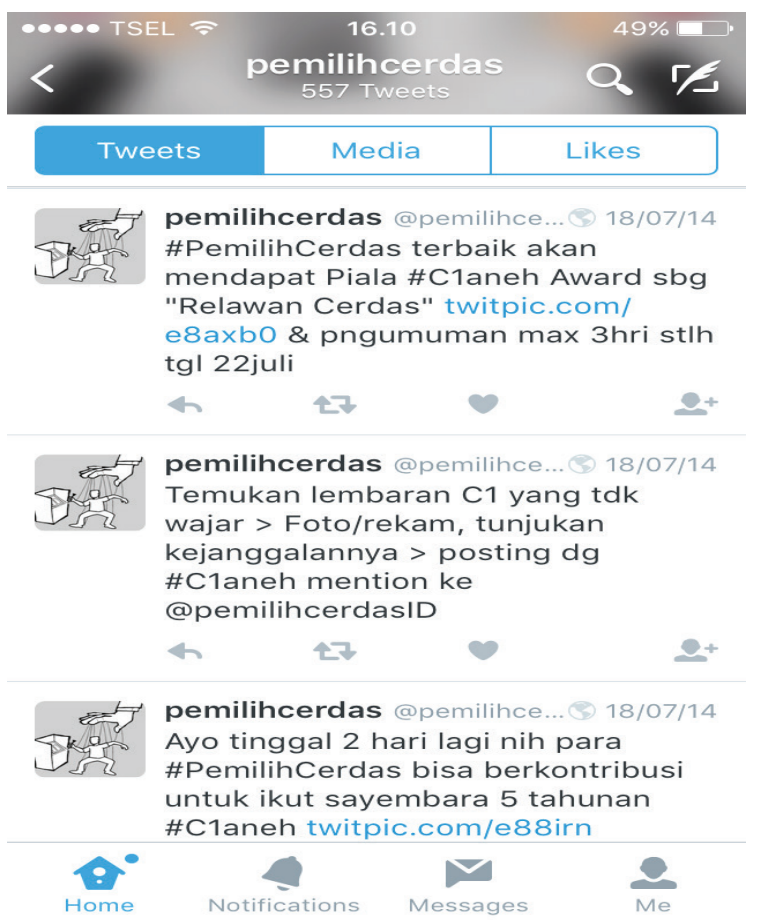

Gambar 2 Tampilan Pesan Twitter Pemilih Cerdas

singkat yang bersifat persuasif untuk mengajak masyarakat kota Bandung ikut berpartisipasi dan mengawasi proses pemilu. Setelah proses penyeleksian berita atau informasi yang di buat oleh anggota timses relawan media sosial, maka dipilih tiga berita utama yang akan di posting setiap hari secara berkala di akun Twitter.

Pesan-pesan kampanye yang ingin disampaikan melalui Twitter akan disusun sedemikian rupa agar tampak lebih menarik dan selalu memiliki kesan edukatif bagi semua orang yang membaca. Melalui Twitter kegiatan kampanye akan lebih sedikit mengalami kegagalan, artinya tidak akan ada kesalahan dalam berbicara, tidak ada pihak-pihak yang ingin mengambil kesempatan dalam proses kampanye, serta menjadikan pesan-pesan yang disampaikan lebih fokus kepada masyarakat bukan kepentingan pribadi.

Proses kampanye yang dilakukan oleh timses relawan media sosial melalui Twitter dilakukan melalui tiga kegiatan inti yaitu pertama anggota timses relawan media sosial menyediakan beberapa konsep yang dianggap akan menarik perhatian khalayak di kota Bandung salah satunya ketika timses mengangkat cerita tentang kegemaran calon presiden Joko Widodo terhadap musik metal, Jokowi selalu mendengarkan musik metal ketika ia berada di dalam mobil disela-sela kegiatannya sebagai gubernur DKI Jakarta saat itu. Jokowi juga berkesempatan hadir untuk menonton konser Metallica band beraliran heavy metal asal Amerika serikat ketika mengadakan konser di Jakarta pada agustus 2013.

Timses relawan media sosial menjadikan jejaring sosial Instagram sebagai media yang akan menyalurkan informasi-informasi tentang kegiatan-kegiatan Jokowi-Jk dalammenjalankan tugas sebagai abdi Negara. Terdapat tiga akun Instagram pendukung yang dikelola oleh timses relawan media sosial, yaitu @Pemilih_bersih, @IrJokowidodo,@Jusufkalla. Akun Instagram Pemilih_bersih lebih fokus kepada tata cara atau regulasi yang benar dalam proses pemilu bukan sebagai media yang fokus kepada kegiatankegiatan Jokowi-Jk.

Melalui akun Instagram pribadinya, Jokowi memperkenalkan kepada masyarakat khususnya followers nya tentang program kerja. ia menjelaskan tentang program kerja yang akan direalisasikan dalam jangka waktu yang sudah ditentukan. Ketika Jokowi berkunjung ke suatu daerah untuk menjalankan program kerjanya, ia memastikan beberapa pertanyaan dasar yang harus ditanyakan, yaitu Apa saja masalah yang terjadi, apa yang diperlukan untuk membantu masyarakat sekitar, bagaimana tanggapan pemerintah daerah ketika masyarakat mengadukan keluhan.

Program kerja dijelaskan secara gamblang melalui akun Instagram dilengkapi dengan fotofoto yang berkaitan. Jokowi juga menjelaskan bagaimana langkah awal program kerja tersebut direalisasikan. Apa saja strategi yang 
diterapkan untuk memenuhi semua target yang sudah ditentukan sejak awal. Jokowi ingin seluruh masyarakat melalui media apapun, termasuk media sosial untuk menikmati dan ikut berpartisipasi, serta memberikan masukan yang membangun tentang program kerja yang diberikan.

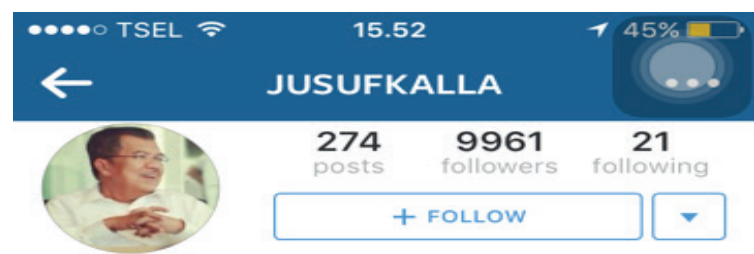

Jusuf Kalla

Wakil Presiden Republik Indonesia www.wapresri.go.id

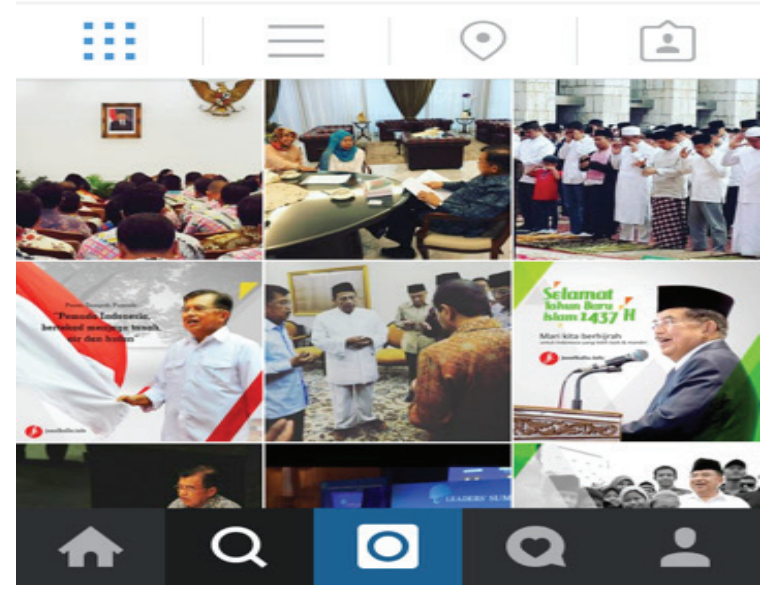

Gambar 3 Tampilan Instagram JUSUF KALLA

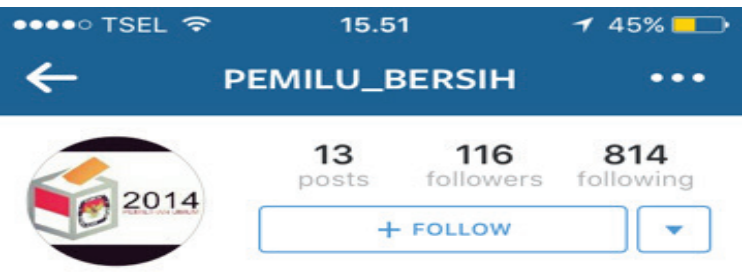

pemilu_bersih

Yuk kita jadi warga negara yg peduli pemilu. Upload foto/video dgn : \#pantaupemilu14 siapa tau anda mnemukan hal menarik slama masa tenang ini.Thks^^ www.pemilubersih.org

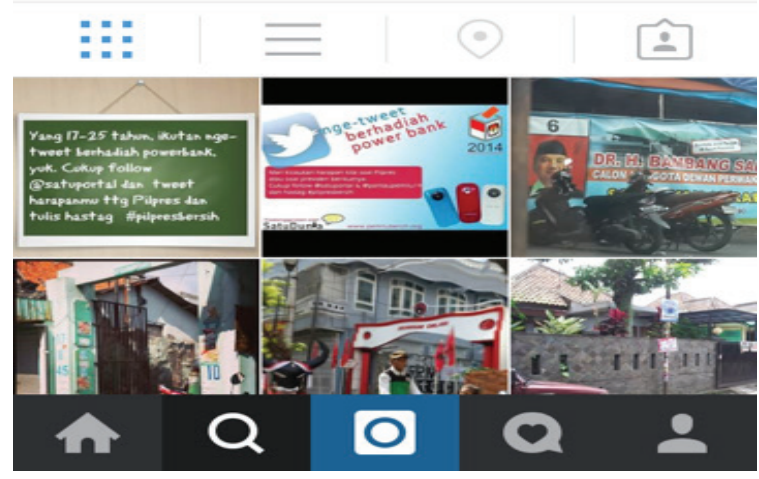

Gambar 4 Tampilan Instagram PEMILU_BERSIH

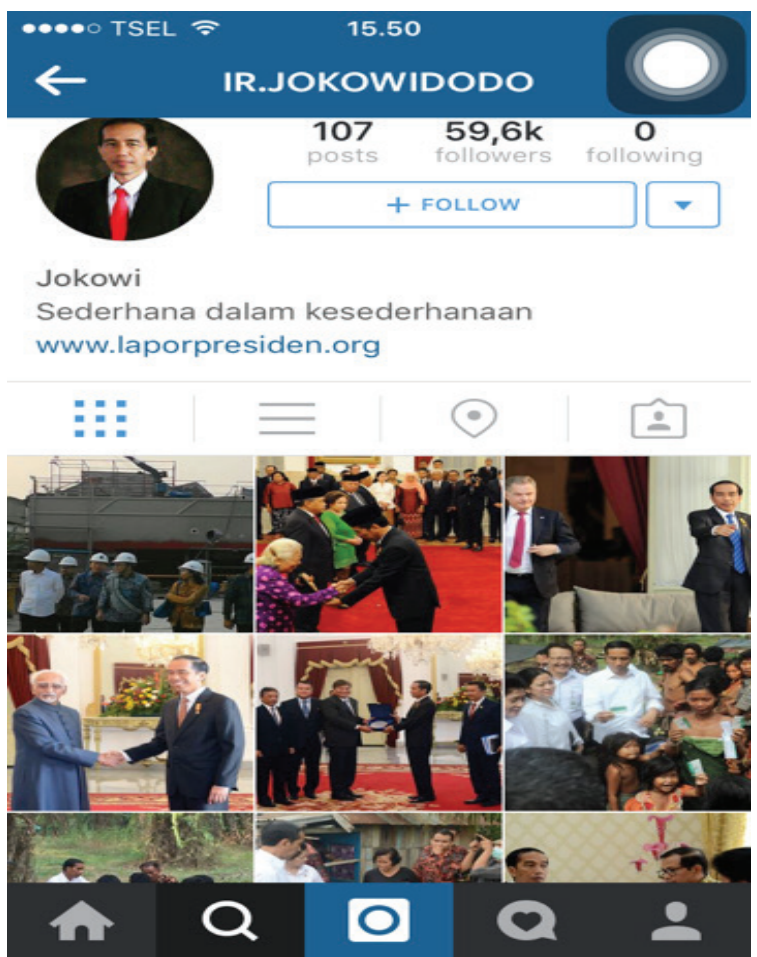

Gambar 5 Tampilan Instagram IR_JOKOWIDODO

\section{SIMPULAN}

Timses relawan media sosial Jokowi-Jk di Bandung mengidentifikasi beberapa media, yaitu media cetak, media eletronik dan media sosial. Ketiga jenis media tersebut memilki kelebihan dan kekurangan masing-masing. Media sosial akhirnya dipilih sebagai media utama yang akan menjadi media komunikasi sebagai penghubung dan penyampai pesan serta informasi kepada khalayak, terutama masyarakat kota Bandung. Pesan bersifat ajakan yang berisikan informasi seputar pemilu 2014 disebarkan melalui media sosial secara berkala.

Media sosial menjadi media utama dalam proses penyampaian pesan kepada khalayak di kota Bandung. Terdapat beberapa jenis media sosial yang akan digunakan secara rutin dalam proses tersebut, yaitu Twitter, Facebook, Instagram, dan Youtube. Namun, timses relawan media sosial hanya fokus kepada dua jenis media sosial yang dianggap dapat mempengaruhi pandangan publik. Twiter dan Instagram dianggap mampu menjadi jejaring sosial yang efektif dalam proses penyampaian pesan politik pemilu 2014.

Penyampaian informasi oleh timses relawan media sosial kepada masyarakat melalui Twitter dianggap sangat efektif dan 
tepat. Konten-konten yang disediakan oleh akun Twitter sangat mudah untuk diakses oleh semua kalangan. Sebelum menentukan nama akun Twitter yang sesuai, timses relawan media sosial menyeleksi beberapa kandidat nama akun, yaitu@ayoikutpemilu, @pemilihcerdasid,@indonesiamemilih,dan @pemilu2014pintar. Pada akhirnya terpilih nama akun@pemilihcerdaid sebagai pilihan nama yang paling tepat untuk mengawali proses penyampaian informasi melalui akun Twitter.

Sama halnya dengan jejaring sosial Twitter, Instagram menjadi media sosial yang difokuskan dalam proses penyampaian informasi. Instagram mampu menjadi media yang menarik perhatian khalayak melalui konten-konten yang ditawarkannya. Kontenkonten yang sebagian besar berisikan fotofoto membuat Instagram menjadi media sosial yang memilki variasi dibandungkan dengan media sosial lainnya.

Dipilih tiga akun Instagram yang akan mewakili timses relawan dalam proses penyampaian informasi yaitu akun Instagram yang dibuat oleh timses relwan media sosial media itu sendiri bernama PEMILU_BERSIH, yang kedua akun Instagram pribadi milik calon presiden Joko Widodo dan yang terakhir akun Instagram milik Jusuf Kalla.

Timses relawan media sosial melakukan survei kepada pengusaha muda dibidang usaha kreatif yang aktif menggunakan smartphone yang bertujuan mengetahui seberapa sering mereka menggunakan smartphone dalam mengakses informasi melalui media sosial. Hasilnya menunjukkan bahwa $87 \%$ kalangan pengusaha muda sangat bergantung kepada smartphone yang mereka gunakan.

Timses relawan media sosial menjadikan hasil survei tersebut sebagai patokan untuk menyediakan informasi tentang pemilu 2014 berdasarkan kebutuhan masyarakat kota Bandung. Informasi yang disebarkan secara rutin dan tentu saja memilki keakuratan data, sehingga warga masyarakat tidak mudah terprovokasi oleh akun-akun Twitter yang tidak jelas sumber informasinya.

Dua tujuan utama timses relawan media sosial media menggunakan jejaring sosial Twitter sebagai proses penyampaian informasi kepada khalayak adalah sebagai proses pertukaran pesan dan informasi timses relawan dengan masyarakat kota Bandung dan sebagai proses penyampaian informasi yang berkaitan dengan pelaksanaan pemilu 2014 di kota Bandung. Pertukaran pesan pada akun Twitter @pemilihcerdasid biasanya akan melewati beberapa proses untuk penggunaannya. Biasanya masyarakat kota Bandung sering mengajukan pertanyaan-pertanyaan sederhana tentang bagaimana proses pemilu yang ideal dan berdasarkan aturan yang berlaku.

Tujuankeduasebagaiproses penyampaian informasi singkat yang berkaitan dengan pelaksanaan pemilu, informasi tersebut bersifat persuasif untuk mengajak warga masyarakat kota Bandung berpartisipasi langsung dalam proses pemilu tersebut. Berbeda dengan tujuan yang pertama, proses penyampaian informasi ini bersifat satu arah, artinya followers mengajukan pertanyaan ataupun tanggapannya, ini dikarenakan informasi yang sudah disusun dan dirangkai sifatnya informatif.

Penelitian ini adalah sebuah usaha untuk mengetahui penerapan literasi media sebagai strategi komunikasi tim sukses relawan pemenangan presiden Joko Widodo dan Jusuf Kalla di kota Bandung, dengan menggunakan pendekatan studi kasus, tujuan utama penelitian ini adalah untuk mengetahui proses literasi media sehingga sukses relawan media sosial di Bandung. Berdasarkan kesimpulan hasil penelitian, selanjutnya penulis memberikan saran karena penelitian ini masih belum sempurna. Saran tersebut penulis tunjukan kepada pihak-pihak yang terkait baik langsung ataupun tidak langsung dengan rumusan penelitian yang penulis lakukan, yaitu:

Penelitian mengenai literasi media dalam bidang komunikasi sangat beragam. Namun penelitian yang mengangkat pembahasan tentang literasi media khususnya media sosial dan komunikasi politik masih sedikit. Oleh karena itu, dengan adanya penelitian tantang proses literasi media tim sukses relawan pemenangan presiden Jokowi-Jk ini dapat menambah masukan bagi ilmu komunikasi, terutama dalam bidang literasi media, bahwa saat ini keberadaan media dapat menjadi sebuah strategi komunikasi yang cukup efektif.

Penelitian ini penulis lakukan untuk mengetahui proses literasi media yang 
diterapkan oleh tim sukses relawan pemenangan presiden Joko Widodo dan Jusuf Kalla di Bandung. Selama melakukan penelitian ini, penulis kurang mendapatkan sumber informasi berupa dokumentasi mengenai literasi media atau aspek-aspek komunikasi pada tempat penulis melakukan penelitian. Sehingga melalui penelitian ini, penulis ikut menyumbangkan informasi mengenai komponen-komponen literasi media sesuai dengan teori terkait. prosesproses literasi media yang dilakukan oleh timses relawan media sosial pemenangan Jokowi-Jk di kota Bandung masih sangat sederhana, sesuai dengan pengetahuan dari anggota timses media sosial saja. Diharapkan penelitian ini dapat membantu proses-proses literasi media untuk melakukan kegiatankegiatan politik melalui media.

Pendekatan teori yang digunakan dalam acuan penelitian ini tidak hanya melalui teori literasi media saja, banyak teori-teori terkait seperti analisis framing dan komunikasi politik. Mengingat penelitian ini hanya meneliti tentang proses-proses penerapan literasi media pada tim sukses relawan pemenangan presiden Jokowi-Jk di kota Bandung, oleh karena itu penulis menyarankan untuk dilakukan penelitian lanjutan mengenai literasi media di tempat penelitian yang berbeda, agar dapat mengembangkan teori-teori yang bersangkutan.

Penelitian mengenai literasi media dan komunikasi politik sangat luas ruang lingkupnya. Penelitian ini dapat menjadi rujukan atau referensi bagi peneliti yang akan melakukan penelitian sejenis dengan metode yang sejenis pula. Namun, pemahaman yang mendalam tentang literasi media menurut penulis perlu dilakukan oleh para peneliti literasi media.

\section{DAFTAR PUSTAKA}

Alhanin, S. (2009). Modul I: konsep dasar teoritis: komunikasi, informasi, dan perpustakaan. Diakses dari https:// simfonikehidupan.wordpress . com $/ 2009 / 05 / 10 /$ modul-i-konsepdasar-teoritis-komunikasi-informasidan-perpustakaan/

Baran, S. J. (2011). Pengantar Komunikasi massa: literasi media dan budaya. Jakarta: Salemba Humanika.

Basrowi \& Suwandi. (2008). Memahami penelitian kualitatif. Jakarta: Rineka Cipta.

Basuki, S. (2013). Literasi informasi dan literasi digital.Diakses darihttps://sulistyobasuki. wordpress.com/2013/03/25/literasiinformasi-dan-literasi-digital/

Bland, michael., Theaker, A., \& Wragg, D. (2001). Hubungan media yang efektif. Jakarta: Erlangga

Briggs, A. \& Burke, P. (2005). A sosial history of the media: from gutenberg to Internet. Cambridge: Polity Press.

Budiarti, R. T. \& Huda, M. (2013). Himpunan peraturan perundang-undangan bidang pemilu. Jakarta: Konstitusi Press.

Cangara, H. (2013). Perencanaan dan strategi komunikasi. Depok: Rajagrafindo Persada.

Efriza. (2008). Ilmu politik: dari ilmu politik sampai sistem pemerintahan. Bandung: Alfabeta.

Endraswara, S. (2009). Metodologi penelitian kebudayaan. Yogyakarta: Gadjah Mada University Press.

Hasan, E. (2005). Komunikasi pemerintahan. Bandung: Refika Aditama.

Kamaruzzaman. (2015). Teori agenda setting dan framing dalam ilmu komunikasi massa. Diakses dari http://www.academia. edu/12033610/TEORI_AGENDA_ SETTING_DAN_FRAMING DALAM_ILMU_KOMUNIKASI_ MASSA

Moleong, L. J. (2004). Metode penelitian kualitatif. Bandung: Rosdakarya.

Mulyana, D. (2001). Metode penelitian kualitatif. Bandung: Rosdakarya.

Nimmo, D. (1989). Komunikasi politik: khalayak dan efek. Bandung: Remadja Karya Offset.

(1989). Komunikasi politik: komunikator, pesan, dan media. 
Terjemahan: Tjun Surjaman. Bandung: Remaja Rosdakarya.

Pace, R. W. \& Faules, D. F. (2001). Komunikasi organisasi: strategi meningkatkan kinerja perusahaan. Terjemahan: Deddy Mulyana. Bandung: Remaja Rosdakarya

Pawito. (2009). Komunikasi politik: media massa dan kampanye pemilihan. Yogyakarta: Jalasutra.

Rakhmat, J. (2008). Psikologi komunikasi. Bandung: Remaja Rosdakarya.

Ross, L. G. (2008). Corporate reputation. New Jersey: Jhon Wiley \& Sons,Inc.
Sugiyono. (2005). Memahami penelitian kualitatif. Bandung: Alfabeta.

Tamburaka, A. (2013). Literasi media: cerdas bermedia khalayak media massa. Depok: Rajagrafindo Persada.

Wasesa, S. A. (2011). Political branding public relations. Jakarta: Gramedia Pustaka Utama.

Yin, R. K. (2008). Studi kasus: desain dan metode. Jakarta: RajaGrafindo Persada.

Yulk, G. (2001). Leadership in organization. New Jersey: Prentice-Hall. 